\title{
Lithostratigraphy and Biostratigraphy of the Sarvak Formation in Wells No. 2, 16 and 66 of Rag-e-Safid Oilfield in the Southwest of Iran
}

\author{
Mahboubeh Jamalpour'1, Bahauddin Hamdi ${ }^{2}$, Afshin Armoon ${ }^{3}$ \\ ${ }^{1}$ Department of Geology, Faculty of Science, North Tehran Branch, Islamic Azad University, Tehran, Iran \\ ${ }^{2}$ Institute for Earth Science, Geological Survey of Iran, Tehran, Iran \\ ${ }^{3}$ National Iranian South Oilfields Company, Ahwaz, Iran \\ Email: mahjamal1367@yahoo.com
}

How to cite this paper: Jamalpour, M., Hamdi, B. and Armoon, A. (2017) Lithostratigraphy and Biostratigraphy of the Sarvak Formation in Wells No. 2, 16 and 66 of Rag-e-Safid Oilfield in the Southwest of Iran. Open Journal of Geology, 7, 806-821. https://doi.org/10.4236/ojg.2017.76055

Received: April 30, 2017

Accepted: June 6, 2017

Published: June 9, 2017

Copyright $\odot 2017$ by authors and Scientific Research Publishing Inc. This work is licensed under the Creative Commons Attribution International License (CC BY 4.0).

http://creativecommons.org/licenses/by/4.0/

\begin{abstract}
The lithostratigraphy and biostratigraphy specifications of the Sarvak Formation are considered to study in wells No. 2, 16 and 66 of Rag-e-Safid oilfield. They are located at the southeast of Ahwaz (the southwest of Iran). The lithology of the Sarvak Formation in all the wells mostly consists of limestone. The depth of the Sarvak Formation in well No. 2 is 720 m; in this well, the Sarvak Formation overlies the Kazhdumi Formation and underlies the Papdeh Formation. Vertical distribution of recognized foraminifera, macrofossils and calcareous Algae identifies two biozones: 1) Favusellawashitensis Range zone; 2) Praealveolinacretacea-Ovalveolina ovum \& Rudistfragment Ass. zone. The thicknesses of the Sarvak Formation in wells No. 16 and 66 are about $100 \mathrm{~m}$ and $108 \mathrm{~m}$, respectively; in a part of the Sarvak Formation, drilling was completed, while its upper boundary is covered with the Papdeh Formation, in both wells. In terms of biostratigraphy studies in wells No. 16 and 66, one assemblage biozone is recognized as Praealveolinacretacea-Ovalveolina ovum \& Rudistfragment Ass. Zone, similarly. Finally, the age of the Sarvak Formation is determined as the Cenomanian in three considered wells.
\end{abstract}

\section{Keywords}

Lithostratigraphy, Biostratigraphy, Sarvak Formation, Cenomanian

\section{Introduction}

The NW-SE trending in the Zagros mountain range is located in the south and the southwest of Iran. The geological studies of Zagros have been started since the 19th century and its attraction was raised by oil exploration in Masjed Soleyman. Zagros has economic interests because of its oilfields and it was consi- 
dered by oil geologists for a long time; then, geological studies have been developed significantly since previous century, and they were published as internal reports in National Iranian Oil Company (NIOC). James and Wynd [1] in their report studied stratigraphy of Mesozoic and Cenozoic Formations in three areas: Lorestan, Fars and Khuzestan. Wynd [2] in his report obtained 66 biozones for the Zagros basin and introduced Triassic to Pliocene sediments. Wells [3] did further evaluation on lithostratigraphy facies of the Bangestan group in the Khuzestan region. Khalili [4] reported the biostratigraphy of the Bangestan group in the southwest of Iran. Hart [5] studied palaeontological and historical geology of upper Cretaceous in the Khuzestan region. Amiri-Bakhtiar [6] presented maps of facies and lithofacies for the Sarvak and Ilam Formations in different areas of Zagros.

The southwestern area of Iran has been considered by several researches, where there is one of the most frequent reservoir oilfields in the world. Kalaleh [7] studied the southern area of Dezful embayment and biostratigraphy and lithostratigraphy of the Sarvak and Ilam Formations. Tabatabai [8] studied facies and stratigraphy of the sedimentary environments of the Bangestan group in Kangan and Bozpar anticlines. Ghobeyshavi et al. [9] reported the lithostratigraphy of Ilam and the Sarvak Formations in Ab-Teymour. Ghalavand [10] carried out lithostratigraphy and biostratigraphy of the Sarvak and Ilam Formations in the northeastern part of Dezful embayment and compared them with nearby underground sections. Sajjadi [11] discussed the microscopic biofacies sedimentary of the Zagros basin from Permian to Neogene; then, he revised the biozonation plan of Wynd [2]. Nejad-Shiraziand Abedi [12] carried out their research in the Aptian and Albian deposits (Lower Cretaceous) in the southwest of Iran (Shiraz). Omidvar et al. [13] studied the depositional environment and biostratigraphy of the upper Sarvak Formation in well No. 63 of Ahwaz oilfield. A recent work by Kaviani and Babazadeh [14] considered the eastern area of Iran in the southwest of Qaen; they carried out the biozonation of Lower Cretaceous sediments (Aptian) in Mazarnow and Hassan-Afzal.

In this paper, the stratigraphic succession of the Sarvak Formation is described in three wells of Rag-e-Safid oilfield in the southwest Iran (the southeast of Ahwaz) by two biozones consisting of foraminiera and fragments of macrofossils and calcareous Algae that suggest a Cenomanian age. Then, lithostratigraphic and biostratigraphic columns of the Sarvak Formation are drawn, and the lithostratigraphic columns are correlated for wells No. 2, 16 and 66.

\section{Methods and Materials}

All thin sections (thickness of fossil elements between lams and lamella $40 \mathrm{mi}$ crons) were prepared by the laboratory of NIOC as the following standard method: 1) sample selection among cores and cuttings, 2) putting samples on lams and gluing with Canada-Balsam, 3) rubbing thin sections, 4) putting lamella on sections. A binocular microscope is applied to study these thin sections, and then bioclasts are identified they are very important to determine the age of 
strata. The numbers of the studied thin sections are 574, 469 and 72 for the Sarvak Formation in wells No. 2, 16 and 66, respectively. Then, Log Plot 7 software is applied to plot lithostratigraphy and biostratigraphy columns.

According to Sajjadi and Omidvar [15], Omidvar et al. [13] and Rikhtegarzadeh et al. [16], in this study, recognized biozones are in consistency with the biozones named by Wynd [2]. Despite the Dunham classification system [17] is used to investigate carbonate sedimentary rocks, it was revised by Embry and Klovan [18]; also, the Dunham classification system was applied by Rikhtegarzadeh et al. [16] and Qomi-Aveili [19].

\section{Geographical and Geological Setting}

The Zagros Basin extends from Turkey, north-eastern Syria and north-eastern Iraq through north-western Iran and continues into south-eastern Iran (Figure 1). The Zagros Mountains of Iran are divided into three principal tectonic units (Stocklin [20] and De Jong [21]) namely the Zagros fold-thrust zone, the imbricated zone and the Urumieh-Dokhtar magmatic zone (Alavi [22]). The study area is in the fold-thrust zone of the Zagros Basin (ZFTB in Figure 1) and is located in the Rag-e-Safid oil field, about $150 \mathrm{~km}$ south-east of Ahwaz in south-western Iran (Figure 2(a)). Also, it is surrounded by Bibi Hakimeh oilfield in the east, Pazanan oilfield in the north, Ramshir oilfield in the west and Hendijan and Bahregansar oilfields in the south (Figure 2(b)).

Rag-e-Safid oilfield extends from $30^{\circ} 30^{\prime} \mathrm{N}, 49^{\circ} 4^{\prime} \mathrm{E}$ to $30^{\circ} 10^{\prime} \mathrm{N}, 50^{\circ} 25^{\prime} \mathrm{E}$ at the surface, where is an asymmetric anticline, so the most comprehensive and deepest wells have been drilled almost in the center of the oilfield. This study involves

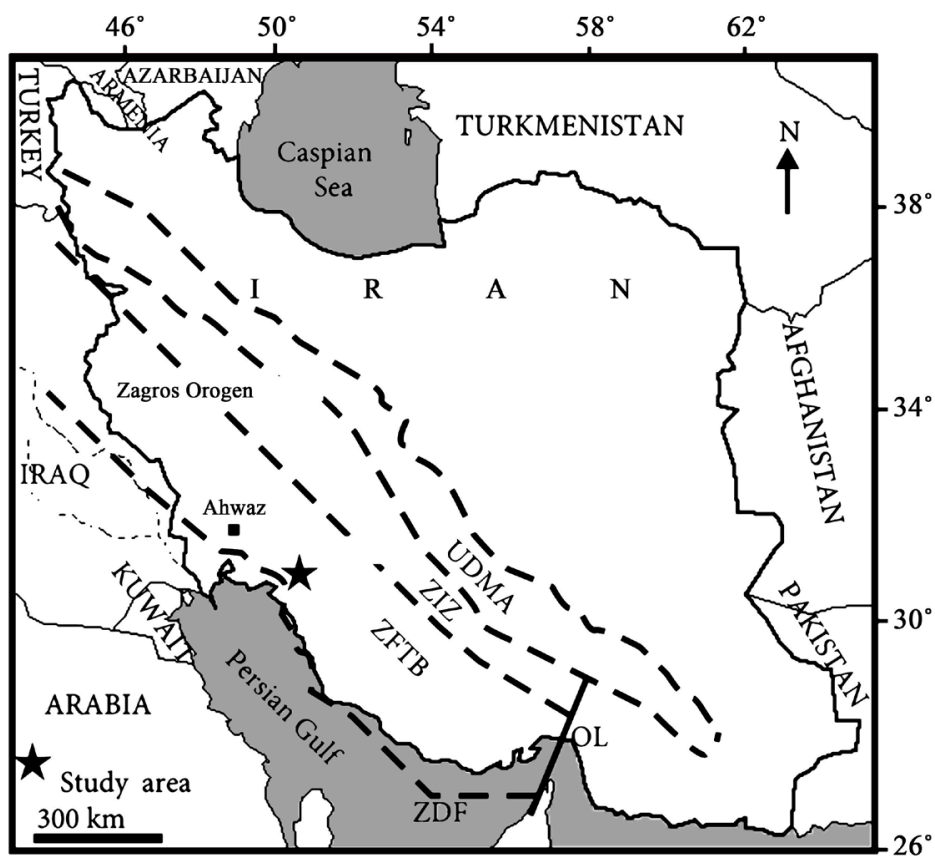

Figure 1. The geological setting of the study area: OL, Oman line; UDMA, UrumiehDokhtarmagmatic arc; ZDF, Zagros deformational front; ZFTB, Zagros fold-thrust belt; ZIZ, Zagros imbricate zone; ZS, Zagros suture (Alavi [22]). 


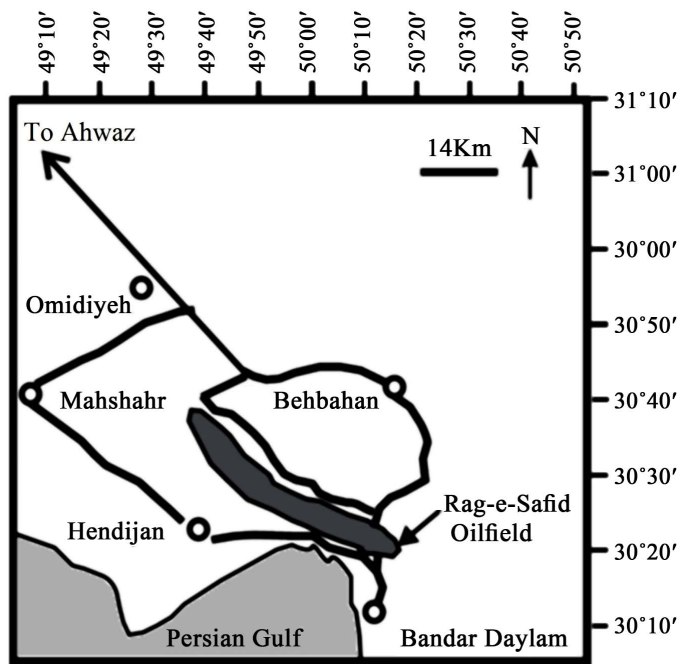

(a)

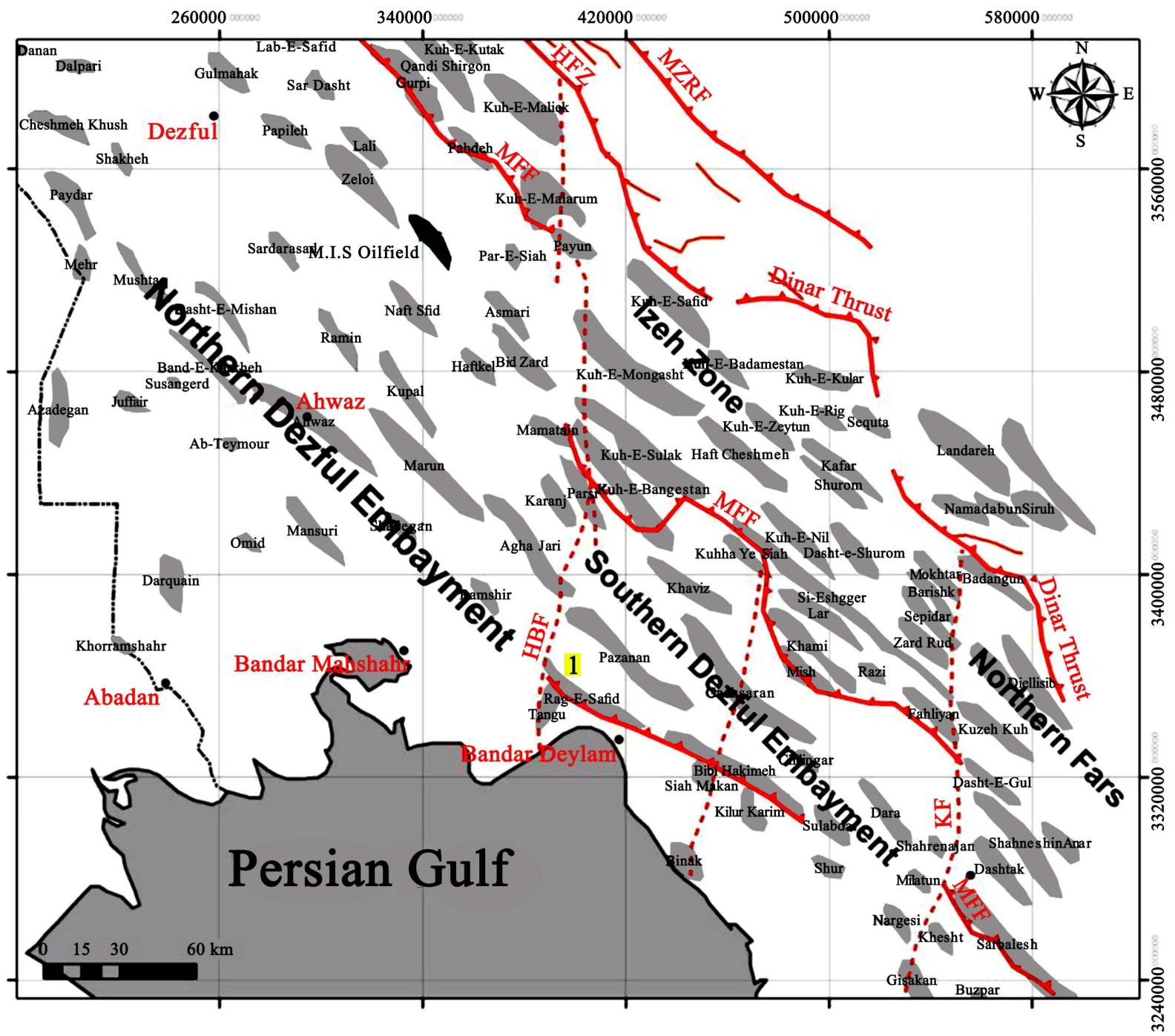

(b)

Figure 2. Location of Rag-e-Safid oilfield (1), in the southwestern Iran [23] [24] ((a): access roads; (b): geographical setting, abbreviations are: MZRF: Main Zagros reverse Fault, MFF: Mountain Front Fault, HZF: High Zagros Fault, KF: Kazerun fault, KMF: Karg-Mish fault, HBF: Hendijan-Bahregansarfault). 
wells numbers 2, 16 and 66 in Rag-e-Safid oilfield. The studied thicknesses of the Sarvak Formation in wells No. 2, 16 and 66 are 720 m, 100 m and 168 m, respectively (Figure 3). Similarly, there is mostly limestone in all the considered wells.

\section{Lithostratigraphy and Biostratigraphy of Well No. 2}

This subsurface section is in the mid northern ridge anticline of Rag-e-Safid oilfield. The Sarvak Formation in well No. 2 has 720 m thickness (from $2582 \mathrm{~m}$ to $3302 \mathrm{~m}$ ), and the lithology of the Sarvak Formation is mostly limestone, and a little dolomite and dolomitic limestone. The Sarvak Formation underlies the Papdeh Formation, and it overlies the Kazhdumi Formation in well No. 2. These boundaries are lithologically distinctive and the following fossils of the Sarvak Formationare observable.

Then, our studies of paleontology in well No. 2 identify foraminifera, macrofossils and calcareous Algae, and there are 11 genera, 54 species of foraminifera, and some macrofossils and calcareous Algae:

Foraminifera: Daxiacenomana, Actinoporellapodolica. H. helvetica, Mangashtiaviennoti, Bacinellairregularis, Rabanitinabasraensis, Edomiareicheli, Reticulinellareicheli, Rotaliporaappenninica, Rotaliporaticinensis, Pseudorhapydioninadubia, Nezzazata concave, Simplalveolina simplex, Cisalveolinafraasi (Guembel [25]), Cisalveolinalehneri, Trocholina elongate, Praealveolina simplex, Pseudorhipidioninacasertana, Montcharmontiaapenninica, Multispirinairanensis, Taberinabangestani, Coxiteszubairensis, Trochospiraavnimelechi, Nummoloculinaregularis, Nummoloculinaheimi, Cycledomiairanica, Praealveolinacretacea, Peneroplisturonicus, Peneropliscairensis (Chiocchini M. [26]), Merlinginacretacea, Biplanatapeneropliformis, Biconcavabentori, Globigerinelloidesbentonensis,

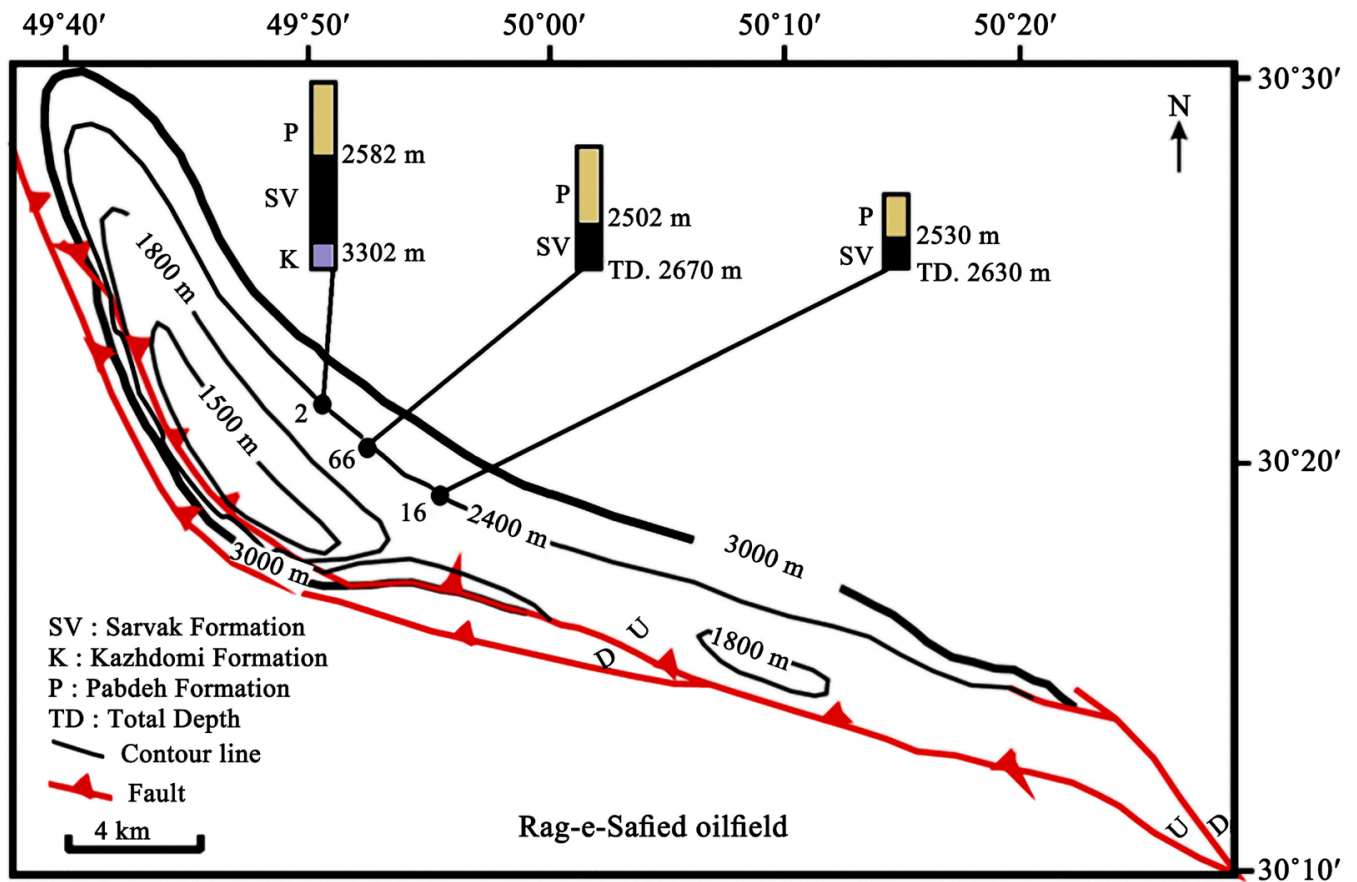

Figure 3. Locations of wells numbers 2, 16 and 66 in Rag-e-Safid oilfield [24]. 
Neoiraqiaconvexa, Dicyclinaschlumbergeri, Chrysalidinagradata, Calcisphaerulainnominata, Favusellawashitensis, Murgeinaapula, Ovalveolina ovum, Nezzazata simplex, Nezzazataconica, Nezzazatagyra, Pithonellaovalis, Pithonellatrejoi, Spiroloculinacretacea, Cuneolinapavonia, Dictyoconuspachymarginalis, N. picardi, Pseudolituonellareicheli, Trocholinalenticularis, Trocholinaaltispira, Permocalculusinnopinata, Stomiosphaerasphaerica, Stomiosphaeraconoidea, Nezzazata sp., Pseudonummoloculina sp., Dictyoconus sp., Peneroplis sp., Karreiella sp., Textularia sp., Heterohelix sp., Globigerinelloides sp., Quinqueloculina sp., Choffatella sp., Miliolid.

Macrofossils and calcareous Algae: Gastropoda, Shell fragment, Sacocomafragment, Ostracod, Algae fragment, Echinoid fragment, Rudistfragment, Sponge spicule, Ellipsactiniasphaeractinoides, Oligostegina.

The biozonations of deposits are done based on Wynd [2], however the international stratigraphic guide [27] is respected. So, the biozones are determined as following and they are shown in Figure 4.

Biozone 1: Favusellawashitensis Range zone

The thickness of biozone 1 is $6 \mathrm{~m}$, its deposits are between $3302 \mathrm{~m}$ to $3296 \mathrm{~m}$, and it is part 1 of well No. 2. The following fossils are observable in biozone 1:

Foraminifera: Stomiosphaeraconoidea, Stomiosphaerasphaerica, Pseudolituonellareicheli, Cuneolinapavonia, Pithonellatrejoi, Pithonellaovalis, Nezzazatagyra, Nezzazataconica, Nezzazata simplex, Favusellawashitensis, Calcisphaerula innominate, Merlinginacretacea, Praealveolina simplex, Textularia sp., Heterohelixsp., Globigerinelloides sp., Choffatella sp.

Macrofossils and calcareous Algae: Oligosteginid.

According to the observed fossils, the age of this biozone is determined as the Cenomanian; so, it is comparable with assemblage biozones 23 by Wynd [2].

Assemblage biozone 2: Praealveolinacretacea-Ovalveolina ovum \& Rudistfragment Ass. zone

The thickness of biozone 2 is $714 \mathrm{~m}$, its deposits are between $3296 \mathrm{~m}$ to 2582 $\mathrm{m}$, and it is part 1 of well No. 2. The following fossils are observable in biozone 2:

Foraminifera: Stomiosphaerasphaerica, Permocalculusinnopinata, Trocholinaaltispira, Trocholinalenticularis, Pseudolituonellareicheli, N. picardi, Dictyoconuspachymarginalis, Cuneolinapavonia, Spiroloculinacretacea, Pithonellatrejoi, Pithonellaovalis, Nezzazatagyra, Nezzazataconica, Nezzazata simplex, Ovalveolina ovum, Murgeinaapula, Favusellawashitensis, Calcisphaerulainnominata, Chrysalidinagradata, Dicyclinaschlumbergeri, Neoiraqiaconvexa, Globigerinelloidesbentonensis, Biconcavabentori, Biplanatapeneropliformis, Merlinginacretacea, Peneropliscairensis (Chiocchini M. [26]), Peneroplisturonicus, Praealveolinacretacea, Cycledomiairanica, Nummoloculinaheimi, Nummoloculinaregularis, Trochospiraavnimelechi, Coxiteszubairensis, Taberinabangestani, Multispirinairanensis, Pseudorhipidioninacasertana, Praealveolina simplex, $H$. helvetica, Actinoporellapodolica, Daxiacenomana, Trocholinaelongata, Cisalveolinalehneri, Cisalveolinafraasi (Guembel [25]), Simplalveolina simplex, Nezzazata concave, Pseudorhapydioninadubia, Rotaliporaticinensis, Reticulinellareicheli, 


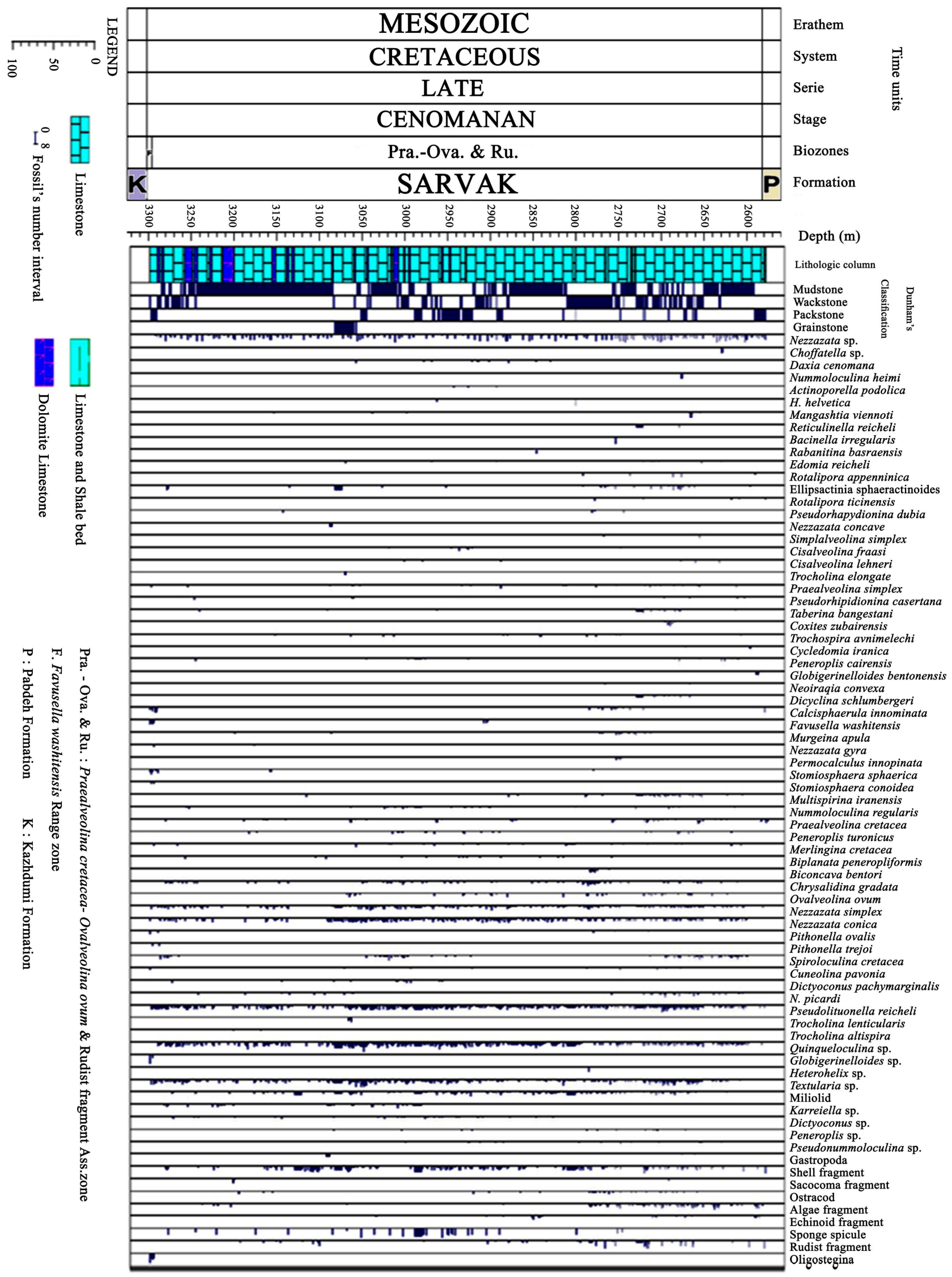

Figure 4. The vertical distribution of foraminifera, macrofossils and calcareous algae of the Sarvak Formation in well No. 2. 
Edomiareicheli, Rabanitinabasraensis, Rotaliporaappenninica, Bacinellairregularis, Mangashtiaviennoti, Heterohelix sp., Cyclolina sp., Quinqueloculina sp., Peneroplis sp., Choffatella sp., Rotalipora sp., Whiteinella sp., Pyrgo sp., Pseudonummoloculina sp., Nezzazata sp., Textularia sp., Dictyoconus sp., Ovalveolina sp., Karreiella sp., Miliolid.

Macrofossils and calcareous Algae: Gastropoda, Shell fragment, Sacocomafragment, Ostracod, Algae fragment, Echinoid fragment, Rudistfragment, Sponge spicule, Ellipsactiniasphaeractinoides.

According to the observed fossils, the age of this biozone is determined as the Cenomanian; so, it is comparable with assemblage biozones 24 and 25 by Wynd [2].

\section{Lithostratigraphy and Biostratigraphy of Well No. 16}

This subsurface section is in the mid southern ridge anticline of Rag-e-Safid oilfield. The thickness of the Sarvak Formation in well No. 16 is $100 \mathrm{~m}$ (from 2530 $\mathrm{m}$ to $2630 \mathrm{~m}$ ), and its lithology is mostly limestone, a little dolomite and dolomitic limestone. In a part of the Sarvak Formation drilling was completed (total depth), while the upper boundary of the Sarvak Formation is covered by the Papdeh Formation. These boundaries are lithologically distinctive and the following fossils of the Sarvak Formation are observable.

Then, our studies of paleontology in well No. 16 identify foraminifera, macrofossils and calcareous Algae, and there are 9 genera, 33 species of foraminifera, and some macrofossils and calcareous Algae:

Foraminifera: Daxiacenomana, Ovalveolinacrassa, Rhapydioninaliburnica, Actinoporellapodolica, Mangashtiaviennoti, Rabanitinabasraensis, Reticulinellareicheli, Cisalveolinafraasi (Guembel [25]), Praealveolina simplex, Pseudorhipidioninacasertana, Taberinabangestani, Trochospiraavnimelechi, Nummoloculinaregularis, Nummoloculinaheimi, Cycledomiairanica, Praealveolinacretacea, Peneroplisturonicus, Peneropliscairensis (Chiocchini M. [26]), Merlinginacretacea, Biplanatapeneropliformis, Neoiraqiainsolita, Dicyclinaschlumbergeri, Chrysalidinagradata, Calcisphaerulainnominata, Murgeinaapula, Ovalveolina ovum, Nezzazata simplex, Nezzazataconica, Spiroloculinacretacea, Dictyoconuspachymarginalis, N. picardi, Pseudolituonellareicheli, Stomiosphaerasphaerica, Nezzazata sp., Ovalveolina sp., Pseudonummoloculina sp., Dictyoconus sp., Karreiella sp., Textularia sp., Heterohelix sp., Quinqueloculina sp., Miliolid.

Macrofossils and calcareous Algae: Gastropoda, Shell fragment, Bryozoa, Ostracod, Algae fragment, Echinoid fragment, Rudistfragment, Sponge spicule, Ellipsactiniasphaeractinoides.

The biozonations of deposits are done based on Wynd [2], however the international stratigraphic guide [27] is respected. So, the following biozoneis determined and it is shown in Figure 5.

Assemblage biozone: Praealveolinacretacea-Ovalveolina ovum \& Rudistfragment Ass. zone

This biozone has $100 \mathrm{~m}$ thickness, deposits are between $2630 \mathrm{~m}$ to $2530 \mathrm{~m}$, 


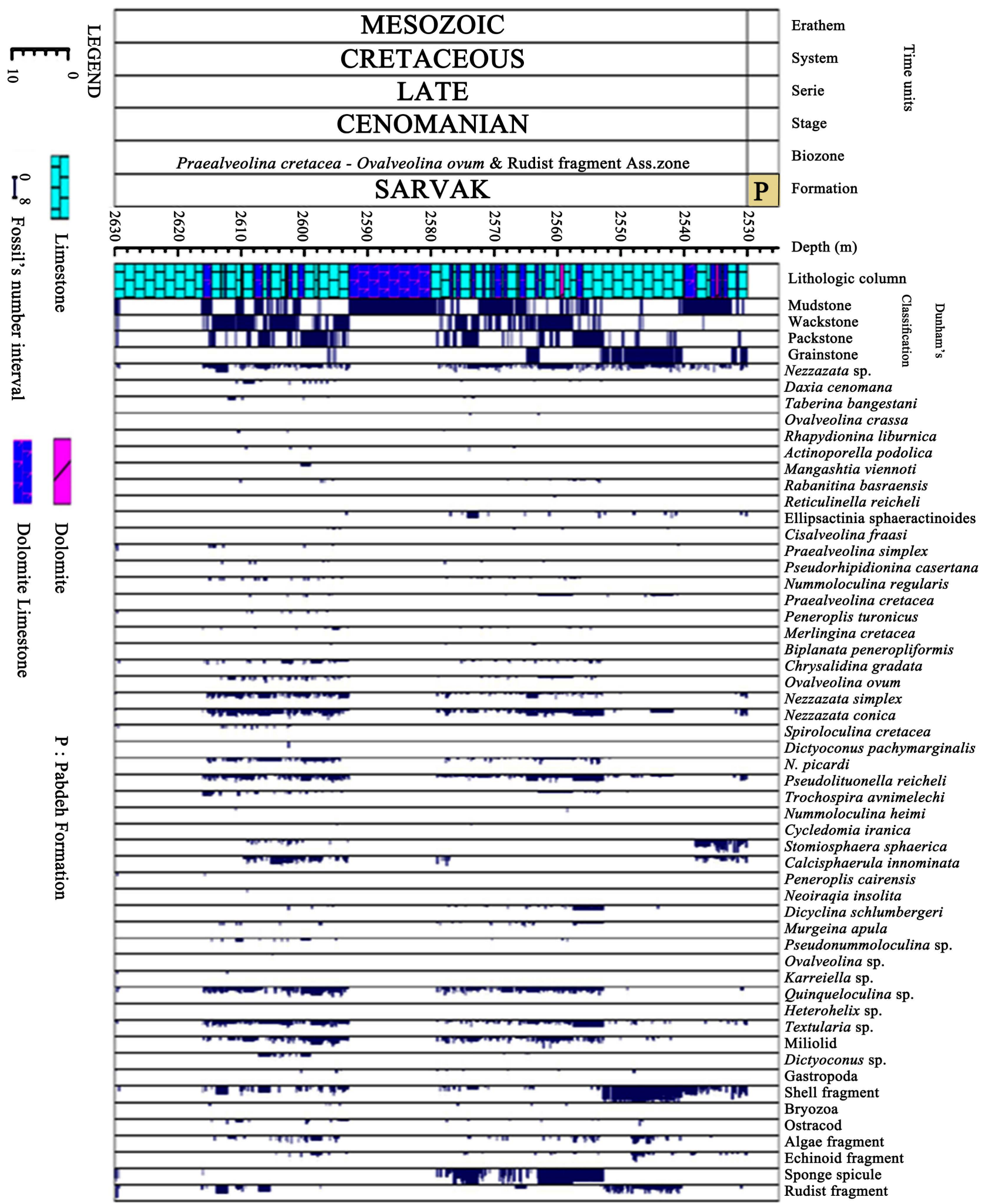

Figure 5. The vertical distribution of foraminifera, macrofossils and calcareous algae of the Sarvak Formation in well No. 16.

and it is part 1 of the considered well No. 16. According to the observed fossils, the age of this biozone is determined as the Cenomanian; so, it is comparable with assemblage biozones 24 and 25 by Wynd [2]. 


\section{Lithostratigraphy and Biostratigraphy of Well No. 66}

This subsurface section is in the mid northern ridge anticline of Rag-e-Safid oilfield. The thickness of the Sarvak Formation in well No. 66 is 168 m (from 2502 $\mathrm{m}$ to $2670 \mathrm{~m}$ ), and its lithology is mostly limestone. In a part of the Sarvak Formation drilling was completed (total depth), while the upper boundary of the Sarvak Formation is covered by the Papdeh Formation. These boundaries are lithologically distinctive and the following fossils of the Sarvak Formation are observable.

Then, our studies of paleontology in well No. 66 identify foraminifera, macrofossils and calcareous Algae, and there are 7 genera, 18 species of foraminifera, and some macrofossils and calcareous Algae:

Foraminifera: Praealveolina simplex, Taberinabangestani, Nummoloculinaregularis, Praealveolinacretacea, Peneropliscairensis (Chiocchini M. [26]), Merlinginacretacea, Biplanatapeneropliformis, Chrysalidinagradata, Murgeinaapula, Ovalveolina ovum, Nezzazata simplex, Nezzazataconica, Spiroloculinacretacea, N. picardi, Pseudolituonellareicheli, Biconcavabentori, Multispirinairanensis, Edomiareicheli, Quinqueloculina sp., Heterohelix sp., Textularia sp., Karreiellasp., Dictyoconus sp., Nezzazata sp., Miliolid.

Macrofossils and calcareous Algae: Shell fragment, Algae fragment, Echinoid fragment, Rudistfragment, Ellipsactiniasphaeractinoides.

The biozonations of deposits are done based on Wynd [2], however the international stratigraphic guide [27] is respected. The following biozone is determined and it is shown in Figure 6.

Assemblage biozone: Praealveolinacretacea-Ovalveolina ovum \& Rudistfragment Ass. Zone

This biozone has $168 \mathrm{~m}$ thickness, deposits are between $2502 \mathrm{~m}$ to $2670 \mathrm{~m}$, and it is part 1 of the considered well No. 66. According to the observed fossils, the age of this biozone is determined as the Cenomanian; so, it is comparable with assemblage biozones 24 and 25 by Wynd [2].

\section{Correlation of the Subsurface Stratigraphic Sections}

An appropriate scale is considered to correlate the stratigraphic sections of the considered subsurface for the Sarvak Formation, and it is plotted for the studied wells (Figure 7). The thickness of the Sarvak Formation in well No. 2 is $720 \mathrm{~m}$ and it is thicker than other considered wells; contrary, its thickness is less in well No. 16 which is $100 \mathrm{~m}$. The Sarvak Formation in all the wells contains mostly limestone. However, the frequency of dolomite in the Sarvak Formation of well No. 16 is more than two other considered wells. However, the lithology of the Sarvak Formation totally consists of limestone in well No. 66; also, limestone and Shale bed successions are shown only in the lithology of the Sarvak Formation in well No. 2.

\section{Conclusions}

The thickness of the Sarvak Formation in well No. 2 of Rag-e-Safid oilfield is 720 


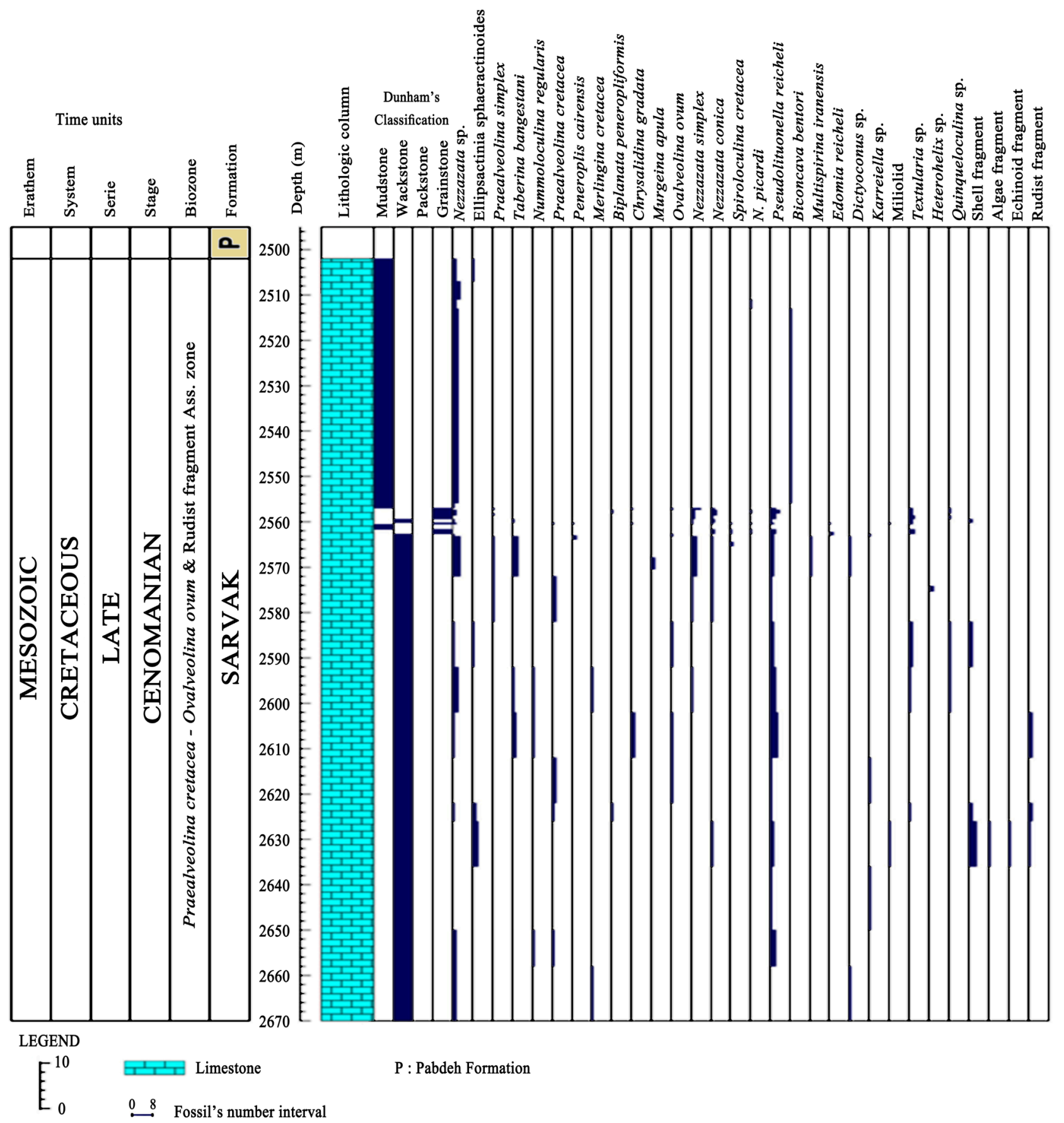

Figure 6. Vertical distribution of foraminifera, macrofossils and calcareous algae of the Sarvak Formation in well No. 66.

m. It contains limestone, lithologically. In the lower boundary, the Sarvak Formation underlies Kazhdumi Formation and its upper boundary is covered by the Papdeh Formation. Our precise studies of fossils and microscopic thin sections identified foraminifera, macrofossils and calcareous Algae, 11 genera, 54 species of foraminifera, and some macrofossils and calcareous Algae. The age of the Sarvak Formation was obtained as the Cenomanian; thus, 2 biozones were determined in well No. 2 .

Biozone 1: Favusellawashitensis Range zone. 


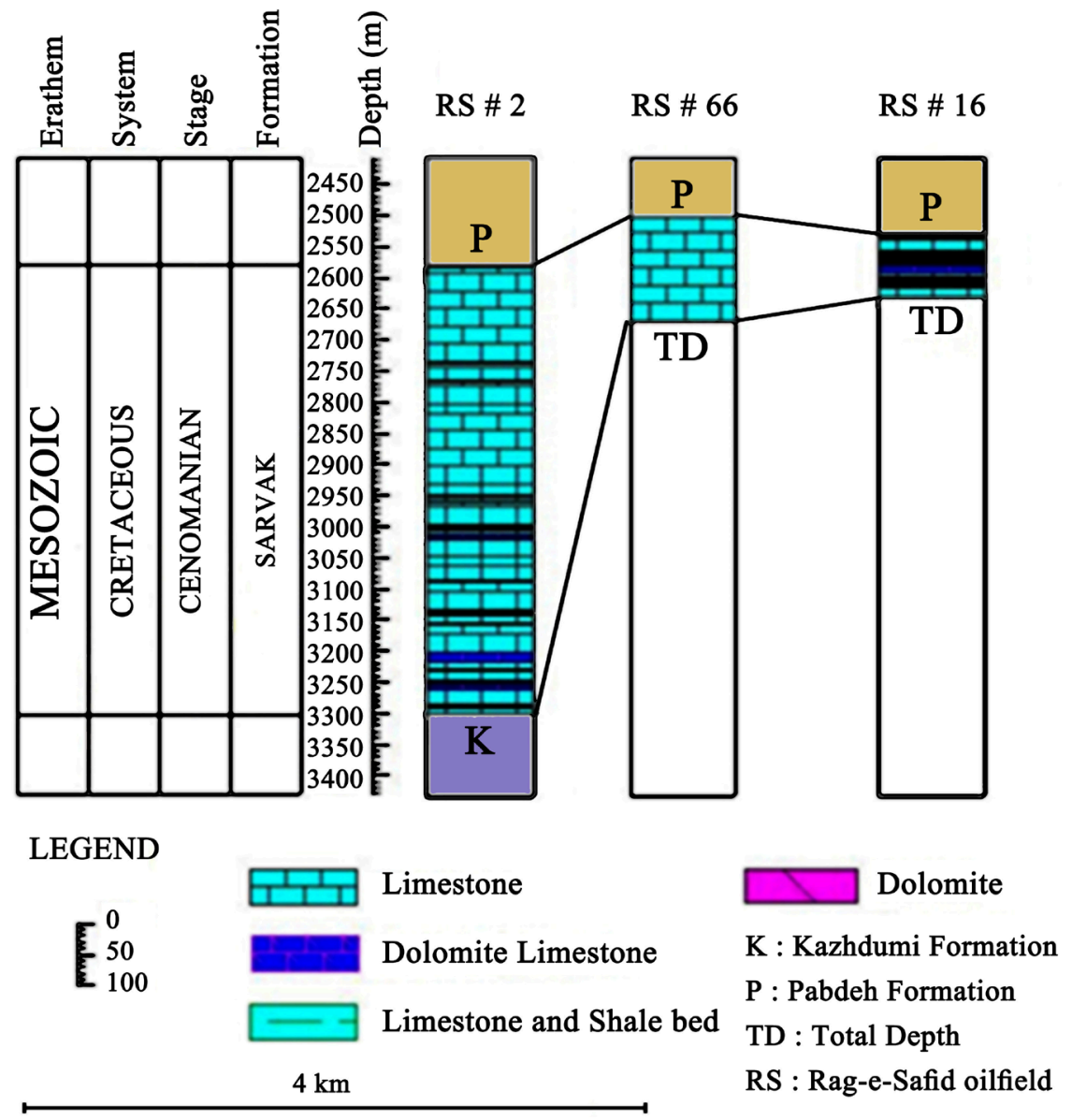

Figure 7. Correlation of the Sarvak Formation lithology in wells No. 2, 16 and 66.

Assemblage biozone 2: Praealveolinacretacea-Ovalveolina ovum \& Rudistfragment Ass. Zone.

The thicknesses of the Sarvak Formation in wells No. 16 and 66 of Rag-e-Safid oilfield are $100 \mathrm{~m}$, and $168 \mathrm{~m}$, respectively. Both contain limestone, lithologically. Also, in a part of the Sarvak Formation, drilling was completed (total depth) and its upper boundary is covered by the Papdeh Formation, similarly. Our precise studies of fossils and microscopic thin sections identified foraminifera, macrofossils and calcareous Algae, 9 genera, 33 species of foraminifera, and some macrofossils and calcareous Algae, for well No. 16; in well No. 66, foraminifera, macrofossils and calcareous Algae, 7 genera, 18 species of foraminifera, and some macrofossils and calcareous Algae were recognized. The age of the Sarvak Formation was obtained as the Cenomanian; thus, 1 assemblage biozone was determined in wells No. 16 and 66, similarly.

Assemblage biozone: Praealveolinacretacea-Ovalveolina ovum \& Rudistfragment Ass. Zone.

\section{Acknowledgements}

The authors would like to thank the National Iranian South Oil Company for providing the thin sections of cores and cuttings. 


\section{References}

[1] James, G.A. and Wynd, J.G. (1965) Stratigraphical Nomenclature of Iranian Oil Consortium Agreement Area. American Association of Petroleum Geologists Bulletin, 49, 2182-2245.

[2] Wynd, J.G. (1965) Biofacies of the Iranian Oil Consortium Agreement Area: Iranian Oil Operating Companies. Geological and Exploration Division Report 1082, 89.

[3] Wells, A.J. (1966) A Reinterpretation of Bangestan Lithofacies in Khuzestan. Iranian Offshore Oil Company, Tehran, Iran, Technical Memo No. 23.

[4] Khalili, M. (1967) The Biostratigraphic Synthesis of the Bangestan Group in Southwest Iran. Oil Service Company of Iran, Tehran, Iran, Report No. 1219.

[5] Hart, B.B.T. (1970) Upper Cretaceous Palaeontological, Structural History \& Prospect of Khuzestan Province, Iran. Iranian Offshore Oil Company, Tehran, Iran, Report No. 1172.

[6] Amiri-Bakhtiar, H. (1991) Biostratigraphical Description of the Sarvak and Ilam Formations in Izeh Region (the Northeast of Khuzestan) and Comparison with Samirom Region. Unpublished M.S.C. Thesis, University of Tehran, Tehran, Iran.

[7] Kalaleh, A.N. (2001) Biostratigraphy and Lithostratigraphy of the Sarvak and Ilam Formations in the Southern Area of Dezful Embayment (Khark-Kohmish). Unpublished M.S.C. Thesis, Tehran University, Tehran, Iran.

[8] Tabatabai, P. (2004) Facies, the Sedimentary Environments and Stratigraphy of the Bangestan Group in Kangan and Bozpar Anticlines in the Southwest of Iran. Unpublished M.S.C. Thesis, Islamic Azad University, North Tehran Branch, Tehran, Iran.

[9] Ghobeyshavi, A., Rahmani, A., Cherik, G.C. and Naseri, N. (2007) Lithostratigraphy of Ilam and the Sarvak Formations in Ab-Teymour Oilfield in the Southwest of Iran. Proceedings of 25 th Symposium of Geosciences, Tehran, Iran.

[10] Ghalavand, H. (2009) Lithostratigraphy and Biostratigraphy of the Sarvak and Ilam Formations in the Northeastern Part of Dezful Embayment and the Comparison of Them and nearby Underground Sections. Unpublished Ph.D. Thesis, Shahid Beheshti University, Tehran, Iran.

[11] Sajjadi, B.H. (2012) Biofacies Microscopic Sedimentary Basin of Zagros PermianNeogene. National Iranian Oil Company Publication, Tehran, Iran.

[12] Shirazi, M.P.N. and Abedi, F. (2013) Lower Cretaceous Orbitolinid (Foraminiferida) Record from the Southwest of Iran (Zagros, Shiraz). Open Journal of Geology, 3, 1-6. https://doi.org/10.4236/ojg.2013.31001

[13] Omidvar, M., Mehrabi, H. and Sajjadi, F. (2015) Depositional Environment and Biostratigraphy of the Upper Sarvak Formation in Ahwaz Oilfield (Well No. 63). Sedimentary Facies, 7, 158-177.

[14] Kaviani, A. and Babazadeh, S.A. (2015) The Biozonation of Lower Cretaceous Sediments (Aptian) in the Stratigraphical Sections Mazarnow and Hassan-Afzal, the Southwest of Qaen. Proceedings of the 19th Symposium of the Geological Society of Iran and 9 th National Geological Conference, Tehran, Iran.

[15] Sajjadi, F. and Omidvar, M. (2011) Biostratigraphy and Determination of the Sarvak Formation Boundary and Lower Part of Ilam Formation in Marun and Ab-Teymur Oilfields. Proceedings of 15 th Symposium of the Geological Society of Iran, Tehran, Iran.

[16] Rikhtegarzadeh, M., Vaziri, S.H., Aleali, M., Amiri-Bakhtiar, H. and Jahani, D. (2016) Microbiostratigraphy, Microfacies and Depositional Environment of the Sar- 
vak Formation in Bi Bi Hakimeh Oil Field (Well No. 29), Southwest Iran. International Journal of Geography and Geology, 5, 194-208. https://doi.org/10.18488/journal.10/2016.5.10/10.10.194.208

[17] Dunham, R.J. (1962) Classification of Carbonate Rocks According to Depositional Texture. In: Ham, W.E., Ed., Classification of Carbonate Rocks, American Association of Petroleum, Geologists Memoir 1, 108-121.

[18] Embry, A.F. and Klovan, J.E. (1971) A Late Devonian Reef Tract on the North Western Banks Island, North West Territories. Bulletin of Canadian Petroleum Geologists, 19, 730-781.

[19] Aveili, J.Q. (2016) Sarvak Formation Reservoir Modeling, in Oilfield Kuhmond (Southwestern Iran). Open Journal of Geology, 6, 1361-1379. https://doi.org/10.4236/ojg.2016.611098

[20] Stöcklin, J. (1968) Structural History and Tectonics of Iran: A Review. American Association Petroleum Geologists Bulletin, 52, 1229-1258.

[21] De Jong, K.A. (1982) Tectonics of the Persian Gulf, Gulf of Oman and Southern Pakistan Region. In: Narin, A.E.M. and Stehli, F.G., Eds., The Ocean Basins and Margins: The Indian Ocean, Elsevier, Amsterdam, 315-351. https://doi.org/10.1007/978-1-4615-8038-6_7

[22] Alavi, M. (2004) Regional Stratigraphy of the Zagros Fold-Thrust Belt of Iran and Its Proforeland Evolution. American Journal of Science, 304, 1-20. https://doi.org/10.2475/ajs.304.1.1

[23] Sherkati, S. and Letouzey, J. (2004) Variation of Structural Style and Basin Evolution in the Central Zagros (Izeh Zone and Dezful Embayment) Iran. Marin and Petroleum Geology, 21, 535-554. https://doi.org/10.1016/j.marpetgeo.2004.01.007

[24] Amirshahkarami, M., Ghabishavi, A. and Rahmani, A. (2010) Biostratigraphy and Paleoenvironment of the Larger Benthic Foraminifera in Wells Sections of the Asmari Formation from the Rag-e-Said Oil Field, Zagros Basin, Southwest Iran. Stratigraphy and Sedimentology Research, 40, 63-84.

[25] Gümbel, C.W. (1872) Über Zwei Jurassische Vorläuferdes Foraminiferen-Geschlechles Nummulinaund Orbitulites. NeuesJahrbuch Für Mineralogie, 241-260.

[26] Chiocchini, M. (2008) New Benthic Foraminifers (Miliolaceaand Soritacea) from the Cenomanianand Upper Turonian of the Monte Cairo (Southern Latium, Central Italy). Memorie Descrittive della Carta Geologica d Italia, L34, 171-202.

[27] Salvador, A. (1994) International Union of Geological Sciences, International Subcommission on Stratigraphic Classification. John Wiley \& Sons, New York. 


\section{Appendix Plates}

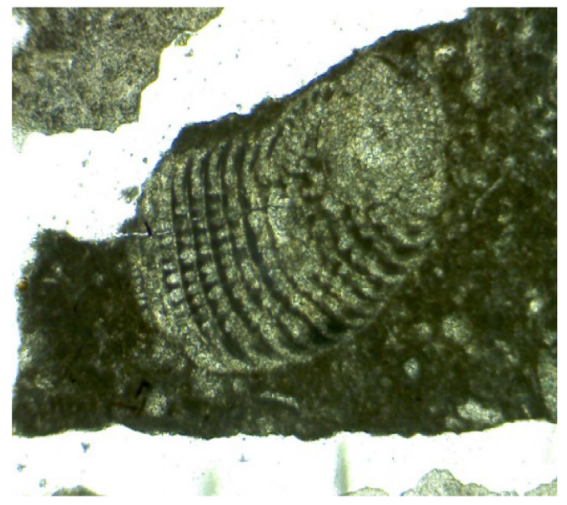

(a)

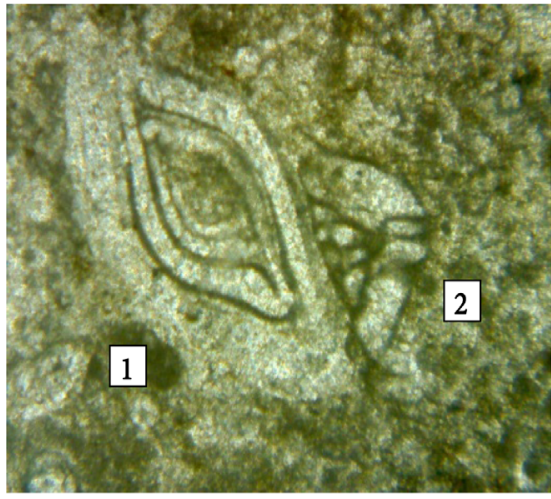

(d)

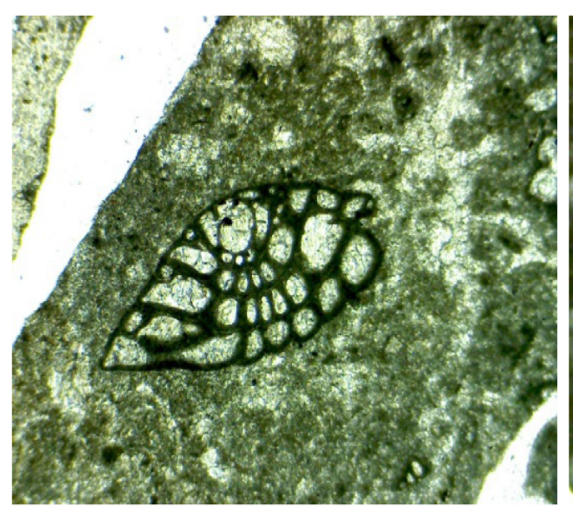

(g)

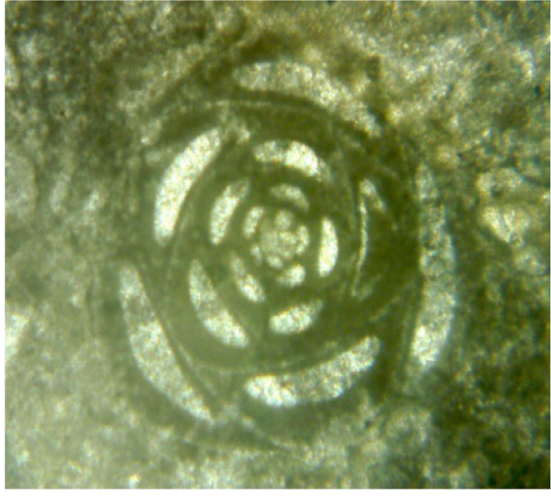

(b)

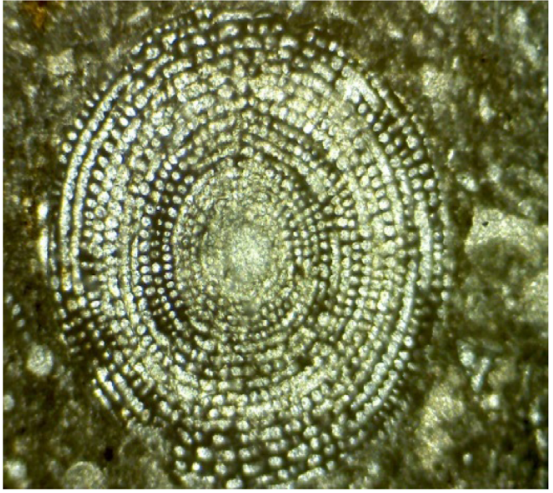

(e)

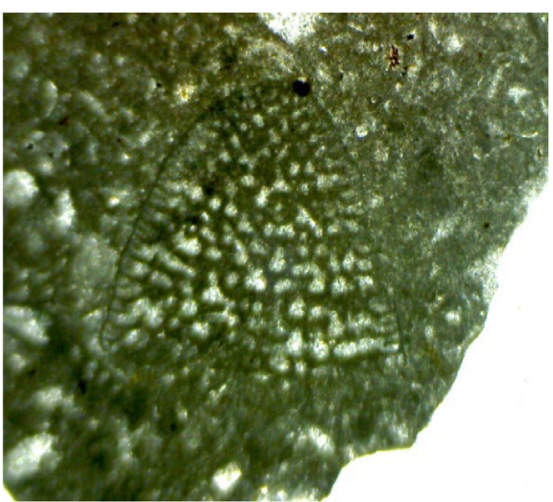

(h)

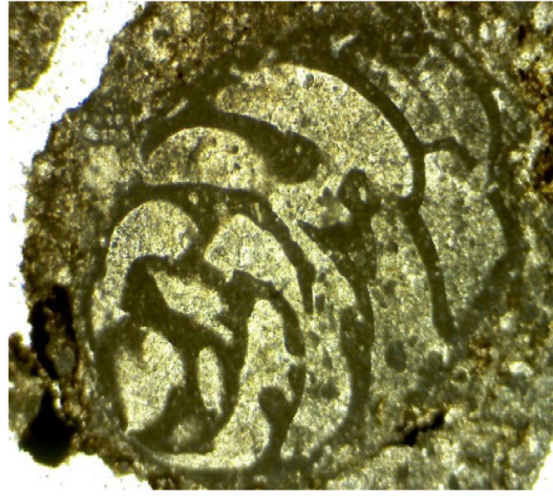

(c)

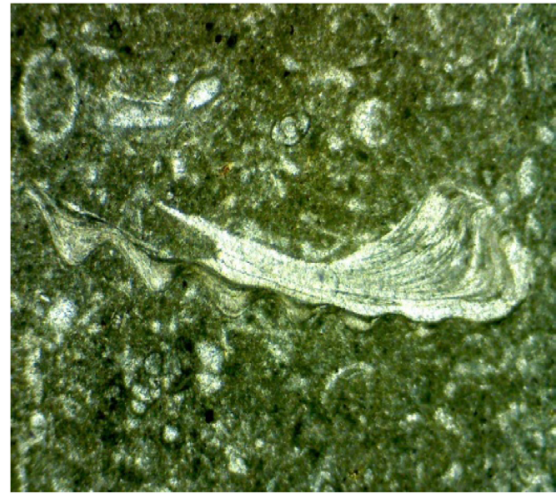

(f)

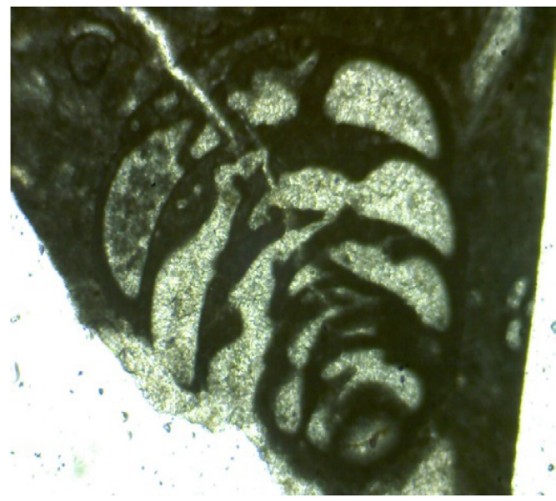

(i)

a) Taberinabingistani, Depth: 2563, X40, RS \#66, Sarvak Formation, Cenomanian.

b) Quinqueloculina sp., Depth: 2638, X100, RS \#2, Sarvak Formation, Cenomanian.

c) Chrysalidinagradata, Depth: 2695, X40, RS \#2, Sarvak Formation, Cenomanian.

d) 1): Spiroloculinacretacea, 2): Nezzazataconica, Depth: 2699, X100, RS \#2, Sarvak Formation, Cenomanian.

e)Multispirinairanensis, Depth: 2790, X40, RS \#2, Sarvak Formation, Cenomanian.

f)Shell fragment, Depth: 2804, X40, RS \#2, Sarvak Formation, Cenomanian.

g) Trochospiraavnimelechi, Depth: 2883, X40, RS \#2, Sarvak Formation, Cenomanian.

h) Dictyoconuspachymarginalis, Depth: 2959, X40, RS \#2, Sarvak Formation, Cenomanian.

i) Chrysalidinagradata, Depth: 2982, X40, RS \#2,Sarvak Formation, Cenomanian. 
Plate 2

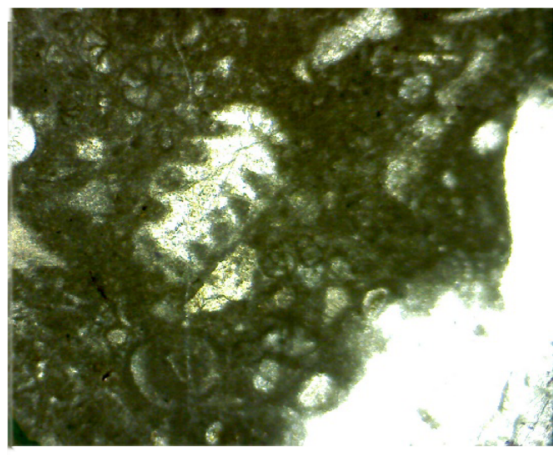

(a)

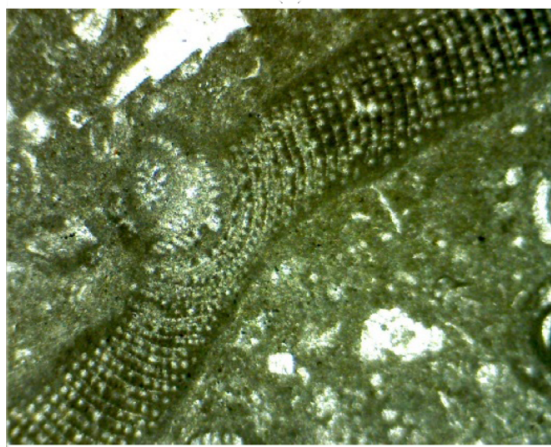

(d)

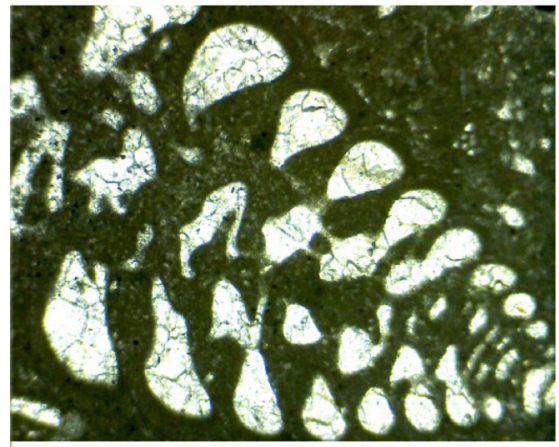

(g)

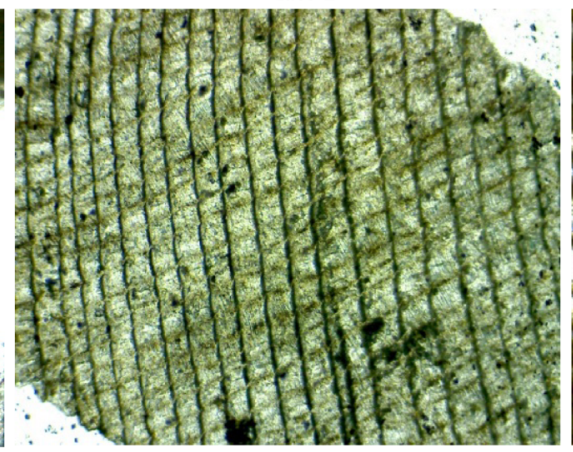

(b)

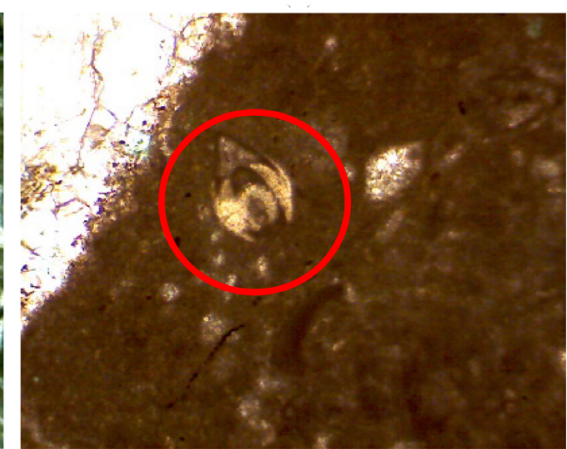

(e)

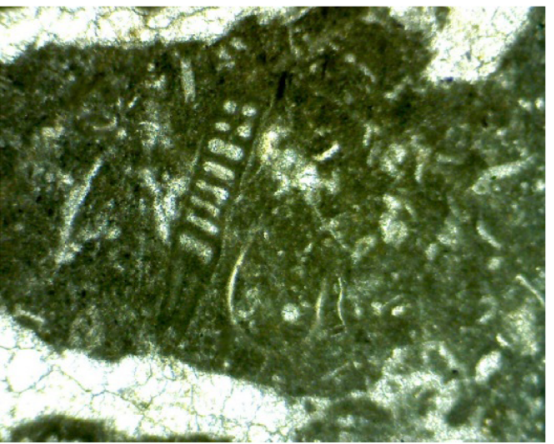

(h)

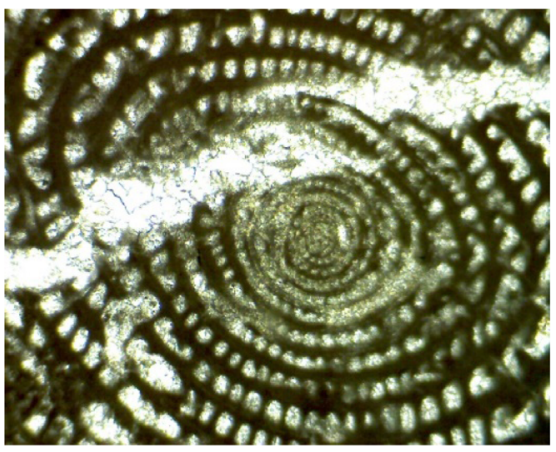

(c)

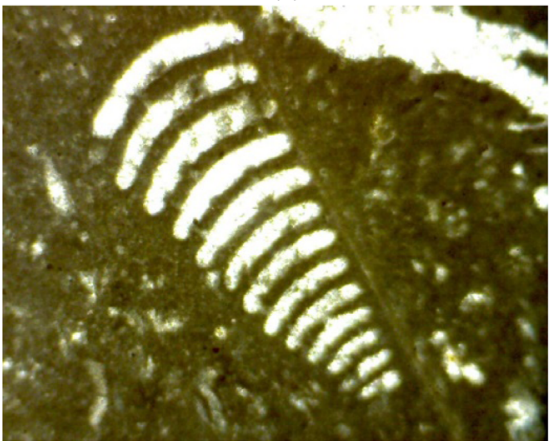

(f)

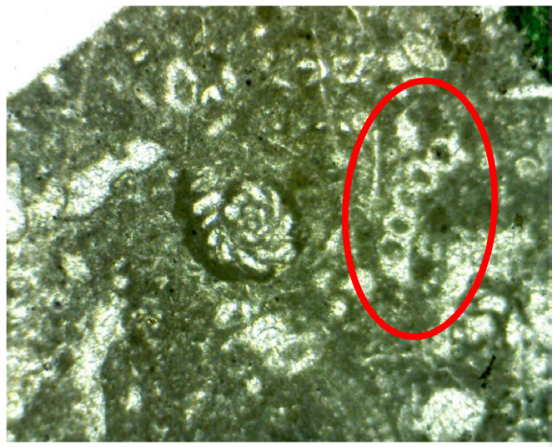

(i)

a) Trocholinalenticularis, Depth: 3066, X40, RS \#2, Sarvak Formation, Cenomanian.

b) Rudistfragment, Depth: 3102, X40, RS \#2, Sarvak Formation, Cenomanian.

c) Praealveolinacretacea, Depth: 2599, X40, RS \#16, Sarvak Formation, Cenomanian.

d) Dicyclinaschlumbergeri, Depth: 2602, X40, RS \#16, Sarvak Formation, Cenomanian.

e) Murgeinaapula, Depth: 2578, X40, RS \#16, Sarvak Formation, Cenomanian.

f) Pseudolituonellareicheli, Depth: 2592, X40, RS \#16, Sarvak Formation, Cenomanian.

g) Chrysalidinagradata, Depth: 2595, X40, RS \#16, Sarvak Formation, Cenomanian.

h) Mangashtiaviennoti, Depth: 2599-2600, X40, RS \#16, Sarvak Formation, Cenomanian.

i) Actinoporellapodolica, Depth: 2599, X40, RS \#16, Sarvak Formation, Cenomanian. 
Submit or recommend next manuscript to SCIRP and we will provide best service for you:

Accepting pre-submission inquiries through Email, Facebook, LinkedIn, Twitter, etc. A wide selection of journals (inclusive of 9 subjects, more than 200 journals)

Providing 24-hour high-quality service

User-friendly online submission system

Fair and swift peer-review system

Efficient typesetting and proofreading procedure

Display of the result of downloads and visits, as well as the number of cited articles Maximum dissemination of your research work

Submit your manuscript at: http://papersubmission.scirp.org/

Or contact ojg@scirp.org 